\title{
Efficiency and Ranking of Indian Pharmaceutical Industry: Does Type of Ownership Matter?
}

\author{
Varun MAHAJAN ${ }^{*}$, D.K. NAURIYAL ${ }^{* *}$, S.P. SINGH ${ }^{* * *}$
}

\begin{abstract}
This paper measures the technical efficiency, super-efficiency, slacks, and input/output targets for large Indian pharmaceutical firms according to ownership by applying Data Envelopment Analysis (DEA) approach. The paper uses raw material, salaries \& wages, advertisement \& marketing and capital usage cost as input variables and net sales revenue as output variable. The super-efficiency model is applied to rank firms on the basis of efficiency scores. The paper finds that mean overall technical efficiency scores of Private Indian and Private Foreign are higher than Group-owned firms, suggesting that type of ownership affects the performance of a given firm. Further, foreign firms were found to have minimum slacks in inputs, evidently owing to their superior technology, better engineering skills and managerial practices. The study suggests that the inputs, such as, advertisement \& marketing expenditure, and also the usage of labour and capital are required to be utilized far more productively in order to improve efficiency.
\end{abstract}

Keywords: Pharmaceutical industry; India; Ownership; Data Envelopment Analysis; Super-efficiency; Ranking; Slack

JEL Code Classification: D24, CO2, C6, L65

\footnotetext{
* Senior Research Fellow. Department of Humanities and Social Sciences, Indian Institute of Technology Roorkee, India. E-mail:mahajan.varun85@gmail.com

** Professor, Department of Humanities and Social Sciences, Indian Institute of Technology Roorkee, India. E-mail: dk nauriyal@yahoo.com

${ }^{* * *}$ Professor,Department of Humanities and Social Sciences, Indian Institute of Technology Roorkee, India. E-mail: singhfhs@iitr.ac.in
}

Copyright @ , 2014 International Ataturk Alatoo University. 


\section{Introduction}

The Indian Pharmaceutical industry (IPI) is considered to be one of the most dynamic and vibrant industries for its prominence among the developing world in being the largest producers and exporters of the generic drugs ${ }^{1}$ across the globe. It meets around 70 per cent of India's demand for bulk drugs ${ }^{2}$, drug intermediates, formulations, fine chemicals, injectibles, tablets, capsules etc. and has also emerged as one of the largest drug exporters in the world. The production costs of Indian pharmaceutical industry are among the lowest in the world, estimated to be 70 percent less than US and Europe (Greene, 2007; Tyagi et al., 2014). Over the last 35 years, this industry, estimated to have grown to be of the worth of US\$22 billion in 2013 and growing at about 8-9 per cent annually, has evolved from almost nonexistent to a world leader in the production of high quality generic drugs estimated by Corporate Catalyst (2014). The industry currently contributes over $10 \%$ of global drug production. Until 1970s, India's pharmaceutical market was dominated by large MNCs with State-owned companies playing at the margin by producing some cheap formulations and bulk drugs. Before amendment of Indian Patent Act 1970, foreign firms controlled about 70 percent of the Indian market (Chaudhuri, 2005). However, this amendment served as a substantial driver of three decades of growth in the domestic pharmaceutical industry, leading to a substantial fall in the drug prices (Hamied, 1993). Another landmark in this regard is the enactment of Product Patent Act in 2005, which significantly altered the business environment, although with the difference that Indian pharmaceutical industry had, by now, established itself as one of the prominent leaders in the production of generic drugs. The new environment necessitated reworking of the business strategies leading to restructuring of the Indian pharmaceutical industry with mergers, acquisitions, liquidation, co-marketing partnerships and creation of brands images (Nauriyal and Sahoo, 2008; Mishra and Chandra, 2010).

The scenario of the Indian pharmaceutical industry has changed over a period of time; the Indian firms have become more technically sophisticated, skilled in reverse engineering and developing new processes for drug production. Over a period of time, it has also evolved to become more diverse and competitive with emphasis on the product differentiation through new combinations and

\footnotetext{
${ }^{1}$ Generic drugs: Copies of off-patent brand-name drugs that come in the same dosage, safety, strength, and quality and for the same intended use. These drugs have received market approval based on proof of bio-equivalence to the originator's product (Grace, 2004).

${ }^{2}$ Drugs: There are two types of drugs: bulk drugs (intermediates) and formulations (i) bulk drugs: The active chemical substances in powder form, the main ingredient in pharmaceuticals - chemicals having therapeutic value, used for the production of pharmaceutical formulations. Major bulk drugs include antibiotics, sulpha drugs, vitamins, steroids, and analgesics and (ii) Formulations: Drugs ready for consumption by patients (generic drugs) sold as a brand or generic product as tablets, capsules, injectables, or syrups. Formulations can be subdivided into two categories: generic drugs and branded drugs (Greene, 2007).
} 
incremental formulation improvements, rather than compromising quality for the sake of surviving only as a low-cost generic alternative.

In view of the fact that the pharmaceutical industry in India encompasses multinationals' subsidiaries, Indian companies and group-owned companies, it would be interesting to find out the difference caused in efficiency by dissimilarity in: access to technology and resources, exposure to international market and best practices, and other characteristics associated with the different types of ownership. In order to do so, this study applies data envelopment analysis (DEA) to measure technical efficiency, rank the firms in order of their super efficiency scores, and estimate input-output slacks as per various types of ownership. The present study makes two notable contributions to the existing literature on the Indian drug and pharmaceutical industry. Firstly, it examines technical efficiency of Indian pharmaceutical firms, as per the type of ownership. Secondly, it is the first to provide a ranking of these pharmaceutical firms as per their super-efficiency scores and slack analysis by differentiating them on the basis of their types of ownership.

\subsection{Ownership Types in the Indian Pharmaceutical Industry}

As indicated earlier, there has been a significant rise in the domestic pharmaceutical sector after the amendment of the Indian Patent Act in 1970, and also a notable decline in the market share of multinationals' subsidiaries. As could be discerned from Figure 1, the share of the latter had declined from around 50 percent in 1990 to 19 percent by 2012, while the share of Indian companies had risen to almost 81 per cent. The growth of the Indian drug and pharmaceutical industry had been much faster after 1990 as compared to years preceding it, precisely because of considerable impact of economic reforms initiated in 1991 and later on. These economic reforms removed much of the bureaucratic controls and regulations and paved the way for swift growth of this industry.

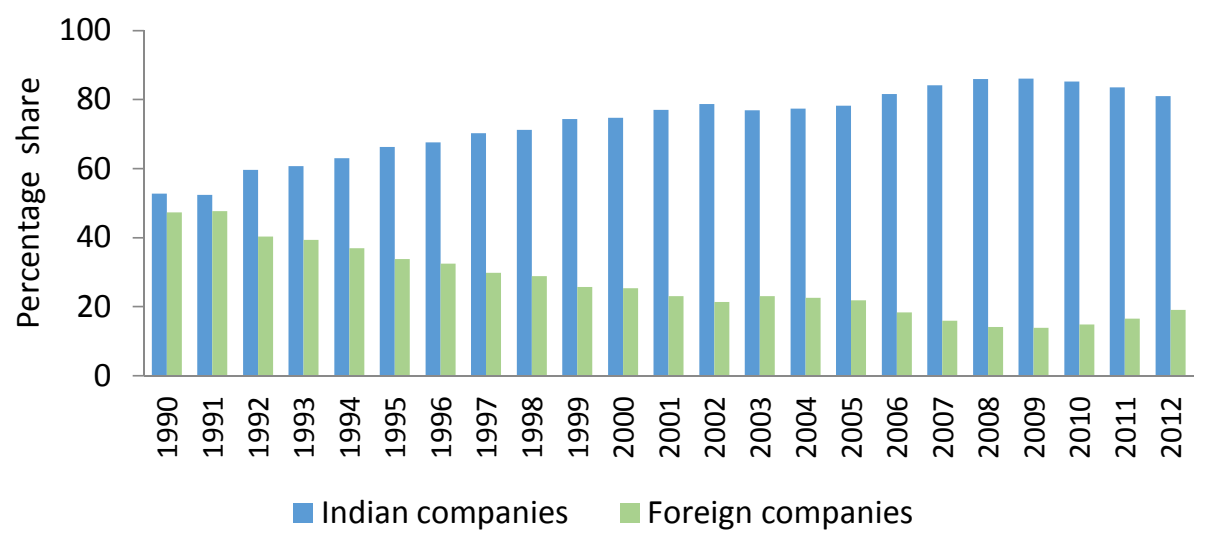

Figure 1: Market Share of Indian and Foreign Companies in Percentage Source: CMIE Prowess, 2013 
There was considerable rise in the exports of pharmaceutical products and fine chemicals. The domestic demand for these products also registered appreciable growth.

The basic difference between Indian and foreign firms is that while Indian firms have greater thrust on portfolio diversification, differentiation, driving down the cost, and incremental innovations; foreign firms appear to be far more technology, brand loyalty, and innovation driven (Cambridge Consultants, 2013).

The remainder of the paper is structured as follows. Section 2 briefly reviews relevant literature on the subject. Section 3 discusses different DEA models used in the study. The data sources and variable construct of inputs and output are discussed in Section 4. Section 5 presents results and discussion, followed by conclusions and policy implications in the last section.

\section{Review of Literature}

DEA has been extensively used to measure the relative efficiency in many subsectors of the Indian economy, such as transport, hospitals, banks, educational institutions, and manufacturing industries like textile, sugar, software industry etc. (Agarwal et al, 2010; Ozcan, 2008; Mogha et al, 2014; Kaur and Kaur, 2010; Kumar and Gulati, 2008; Bayyurt and Duzu, 2008; Joshi and Singh, 2008; Kumar and Arora, 2012). The ranking and slack analysis was applied by Kumar and Gulati (2008) to evaluate the technical efficiency and ranking of public sector banks by applying CCR and super-efficiency models. Majumdar (1998) estimated slacks in resource utilization in Indian and foreign enterprises using DEA and observed significant slacks in inputs utilization in Indian state-owned and domestic firms as compared to foreign firms.

There have also been some studies on the Indian pharmaceutical industry, which have applied various parametric and non-parametric approaches to measure efficiency in the industry. For instance, Chaudhuri and Das (2006) applied the parametric frontier approach to estimate efficiency in the IPI over the period 19902001. Their study showed that the mean efficiency scores of the industry had improved over the period 1999 to 2001 against 1990-1998. Bhasa (2006) empirically examined the performance of 103 firms of various categories for the period 1995-2001 and found evidences of strong relationship between ownership structure and firm performance. It also reported that foreign-controlled firms had registered better performance as compared to their Indian counterparts. Saranga and Phani (2009) used DEA models to assess scale efficiency and pure technical efficiency of IPI and found the evidence of a direct relationship between internal efficiencies and higher growth rates. Saranga (2007) applied multiple objective DEA approach to identify a suitable peer group for inefficient companies and indicated different business strategies to find out the suitable benchmarking peer groups to meet the challenges of IPI. Mazumdar et al., (2009) analysed the output and input efficiencies of the IPI using DEA approach. They found that MNCs operating in India 
were more efficient and productive as compared to domestic firms. Mazumdar and Rajeev (2009) also used DEA to examine the competitiveness of the Indian pharmaceutical firms by computing their technical efficiency scores for the period 1991 to 2005. Saranga and Banker (2010) studied productivity and technical changes in the Indian pharmaceutical industry during 1994-2003 and suggested that high R\&D intensity and wider new product portfolios of MNCs had resulted in positive technical and productivity changes in the industry. Pannu et al. (2011) used DEA models to analyse the relative efficiency and productivity change in the IPI between 1998 and 2007, which covers the post-TRIPS (1995) and post-Indian Patent Amendment Act (2005) periods. They also found that average efficiency of MNCs was higher than the efficiency of indigenous firms. Shivdas (2012) analysed the resource based view of performance measurement and efficiency of pharmaceutical companies in India. He emphasized the need for efficient utilization of resources so as to have sustainable growth of firms. Mahajan et al. (2014) estimated technical efficiencies, slacks, and input/output targets of 50 large Indian pharmaceutical firms for the year 2010-11 and reported that the inefficiency in the firms was either due to inefficient managerial performance or low scale utilization.

On the basis of literature review, we find that there is hardly any study which examines the technical efficiency, ranking, and slacks in the Indian pharmaceutical industry by ownership. There appears to be dearth of studies on efficiency of very large pharmaceutical companies which own an overwhelming proportion of the market share estimated to be at approximately $70 \%$. The efficiency per se has assumed a very high significance in view of the fact that only efficient firms are likely to survive and grow during a period of all pervasive economic slowdown.

\section{DEA Models}

In this study, DEA technique has been used due to its advantages over other techniques, such as stochastic frontier analysis ${ }^{3}$ for measuring the relative efficiency of Indian drug and pharmaceutical industry. First, it helps in estimating overall technical efficiency, pure technical efficiency and scale efficiency. Secondly, DEA handles multiple inputs and outputs without difficulty. Third, it does not necessitate specification of functional form. Fourth, it facilitates in identification of slacks in inputs and outputs and sets targets for inefficient decision making units (DMUs) to make them efficient. Fifth, it sets the benchmark for inefficient DMUs to monitor their efficiency and also identifies sources of their inefficiency.

\footnotetext{
${ }^{3}$ Other popular techniques for measuring relative efficiency of DMUs are Stochastic Frontier Analysis (SFA), Thick Frontier Analysis (TFA), Distribution Free Approach (DFA) and Free Disposal Hull (FDH). SFA is an alternative method for frontier estimation that assumes a given functional form for the relationship between inputs and an output. SFA specifies the functional form of the efficient frontier using econometric methods. The technical efficiency is calculated using the maximum-likelihood estimation of the production subject to random error and inefficiency terms. In this method, there is a possibility of specifying the wrong functional form which results in wrong efficiency estimates. This method is also unable to handle multiple inputs and outputs (Bauer, 1998).
} 
DEA aims to measure the efficient use of inputs available to generate a set of output by a DMU (Charnes et al., 1978). The efficiencies, measured through it are relative to the best performing DMU (or DMUs). Conceptualised and formulated by Charnes, Cooper, and Rhodes (CCR) in 1978 with the assumption of constant returns to scale (CRS), this technique was further enriched by Banker, Charnes, and Cooper (BCC) in 1984 by relaxing the assumption of constant returns to scale. The basic difference between BCC and CCR models is that BCC model assumes variable returns to scale (VRS), while CCR model is based on CRS. If a given DMU is fully efficient in both the CCR and BCC scores, then it is assumed to be operating at the Most Productive Scale Size (MPSS). If a DMU has 100 percent BCC efficiency score but a low CCR score, then it is said to be operating locally efficiently but not globally efficiently due to its disadvantageous scale size. Therefore, it is essential to analyse the impact of size through scale efficiency which is the ratio of these two scores. The decomposition of technical efficiency into pure technical efficiency and scale efficiency helps in depicting the sources of inefficiency i.e., whether the inefficiency is due to inefficient managerial operations (PTE) or due to the negative impact of size shown by the scale efficiency or by both (Cooper et al., 2006).

Efficiency $=\frac{\text { Weighted sum of outputs }}{\text { Weighted sum of inputs }}$

The general DEA model is briefly explained here. In order to describe DEA efficiency evaluation, first, it is assumed that there are ' $n$ ' DMUs. The essential feature of the given ratio construction is the reduction of multiple-output and multiple-input into a single 'virtual-output' and 'virtual-input' respectively. Virtual-output and virtualinput is calculated by the weighed sum of all outputs and weighted sum of all inputs respectively, as:

Virtual input $=\sum_{i=1}^{s} v_{i k} x_{i k}$ Virtual output: $\sum_{j=1}^{s} u_{j k} y_{j k}$

$\max E_{k}=\frac{\sum_{j=1}^{s} u_{j k} y_{j k}}{\sum_{i=1}^{s} v_{i k} x_{i k}}$

Subject to

$\frac{\sum_{j=1}^{s} u_{j k} y_{j r}}{\sum_{i=1}^{m} v_{i k} x_{i r}} \leq 1 \quad \forall r=1,2, \ldots, n$ 
$\frac{u_{j k}}{\sum_{i=1}^{m} v_{i k} x_{i k}} \geq \in \quad \forall j=1,2, \ldots, s$ (1)
$\frac{v_{i k}}{\sum_{i=1}^{m} v_{i k} x_{i k}} \geq \in \quad \forall i=1,2, \ldots, m$

Where $y_{j r}$ is the amount of the $j^{\text {th }}$ output produced by the $r^{\text {th }} D M U ; x_{i r}$ is the amount of the $i^{\text {th }}$ input used by the $r^{\text {th }} D M U ; u_{j k}$ and $v_{i k}$ are the weights given to the output and input; $n$ is the number of DMUs; $s$ is the number of outputs; $m$ is the number of inputs and $\epsilon$ is a very small constant value. It involves finding the values for $\mathrm{u}_{\mathrm{jk}}$ and $_{\mathrm{ik}}$, such that efficiency of the $\mathrm{k}^{\text {th }}$ DMU is maximized, subject to the constraint that all efficiency measures must be less than or equal to one. This fractional problem which is difficult to solve is converted to a linear programming known as multiplier form. The VRS technical efficiency for firm $k$ is estimated by imposing a convexity constraint i.e., $\sum_{i=1}^{m} v_{i k} x_{i k}=1$. After that using the duality in linear programming, one can derive an equivalent envelopment form.

Input Oriented CCR (envelopment) model [2]

$\operatorname{Min} Z_{k}=\phi_{k}-\varepsilon\left(\sum_{j=1}^{s} s_{j}^{+}+\sum_{i=1}^{m} s_{i}^{-}\right)$

Subject to:

$\sum_{r=1}^{n} \lambda_{r} y_{j r}-s_{j}^{+}=y_{j k} \quad, j=1, \ldots \ldots . . s$,
$\sum_{r=1}^{n} \lambda_{r} x_{i r}+s_{i}^{-}=\phi_{k} x_{i k} \quad, i=1, \ldots \ldots . m$,

$\lambda_{r} \geq 0, r=1,2, \ldots . ., n$,

$\phi_{k}$ is unrestricted in sign

$s_{j}^{-}, s_{i}^{+} \geq 0 ; \quad \forall j, i$,

Where $\phi_{k}$ is an efficiency ratio, $s_{j}^{+}$is slack in $j^{\text {th }}$ output of the $\mathrm{k}^{\text {th }} \mathrm{DMU} ; s_{i}^{-}$is slack in the $i^{\text {th }}$ input of the $k^{\text {th }}$ DMU. The objective function is to minimize the efficiency score, $\phi_{k}$, and to maximize input and output slacks of DMU. The model is interpreted as the maximum reduction in inputs of $\mathrm{k}$ DMU that can be done, given that $\mathrm{k}$ DMU has the same reference technology. The constraints (ii) and (iii) form 
the convex reference technology. $s_{i}^{-}, s_{j}^{+} \geq 0$ shows input and output slacks to be non-negative. It is solved $\mathrm{n}$ times for estimating the efficiency of all the DMUs.

DEA identifies the efficient DMU(s) among all DMUs. A DMU is considered Pareto efficient if it is not possible to reduce any input (in case of input-orientation) or increase any output (in case of output-orientation) without reducing output or increasing other inputs. Therefore, the efficient DMU is called a Pareto-optimal unit. DEA scores range between zero to unity, implying that efficient DMUs enjoy the efficiency of unity, while inefficient DMUs have less than unity. The $k^{\text {th }} D M U$ is Pareto efficient if $\theta_{k}^{*}=1$ and all slacks are zero, i.e., $S_{j k}^{+*}$ and $S_{i k}^{-^{*}}=0$ for every j and $\mathrm{i}$. These Pareto efficient DMUs are located on the efficient frontier.

\section{Super Efficiency}

Super-efficiency relates to an amended model in which firms can obtain efficiency scores greater than one because each firm is not permitted to use itself as a peer. Andersen and Petersen (1993) proposed this method and used it to provide a ranking system that helps in discriminating between frontier firms. That is, a firm with a super-efficiency score of 1.25 is better than one with a score of 1.15 because the former is further ahead of its peers, etc. The process of ranking the efficient DMUs is very important so as to differentiate between efficient DMUs and also for the identification of best performer. In super-efficiency model, the DMU under evaluation is excluded from the reference set. In this procedure the value of DMU can become greater than or equal to one. In this way the ranking of DMUs is possible. The super efficiency method has subsequently been used in a number of alternative ways. For example, in sensitivity testing, identification of outliers, and as a method of circumventing the bounded-range problem in a second stage regression method so that standard ordinary least squares regression methods may be used instead of Tobit regression (Coelli, 1998). This method has been applied by many researchers in order to rank universities (Doyle and Green, 1994; SinuanyStern et al, 1994), industries (Sinuany-Stern and Friedman, 1998), banks (Kumar and Gulati, 2008), Sueyoshi and Kirihara, 1998), and hospitals (Yawe, 2010). The functional form of the CCR Super Efficiency Model (envelopment) model is given in equation 3 .

$\operatorname{Min} Z_{k}=\phi_{k}^{\text {supereff }}-\mathcal{E}\left(\sum_{j=1}^{s} s_{j}^{+}+\sum_{i=1}^{m} s_{i}^{-}\right)$

Subject to:

$\sum_{r=1}^{n} \lambda_{r} y_{j r}-s_{j}^{+}=y_{j k}, j=1, \ldots \ldots . s$,

$\sum_{r=1}^{n} \lambda_{r} x_{i r}+s_{i}^{-}=\phi_{k}^{\text {supereff }} x_{i k}, i=1, \ldots \ldots . m$,

$\lambda_{r}(r \neq k) \geq 0, r=1,2, \ldots ., n$, 
$\phi_{k}$ is unrestricted in sign

$$
s_{j}^{-}, s_{i}^{+} \geq 0 ; \quad \forall j, i,
$$

Tone (2002) introduced non-radial super-efficiency models using the Slack-Based Measure (SBM). The efficiency scores from these models are obtained by eliminating the data on the DMU to be evaluated from the reference or solution set. These values are used for ranking the DMUs.

\section{Data Sources and Variable Construct}

\subsection{Data Sources}

The 'PROWESS' of CMIE and 'Capitaline' are primary databases that provide data on a large number of manufacturing firms, including pharmaceutical ones. Although these sources only provide balance-sheet based financial data of the individual companies and do not furnish information about the physical data, such as, number of employees and number of units of output, etc., however, given the limitations of other databases, such as, Annual Survey of Industry (ASI), the relevant cross-sectional data for 50 large firms, having investment in plant and machinery more than Rs. 100 crores for the financial year 2010-11, have been taken from the PROWESS database.

These 50 very large firms, which have been taken up for the present work comprise: Private Indian Owned (21), Private Foreign Owned (07) and GroupOwned (22). The information regarding the rising share of these companies in the Industry's net sales revenue is given in Table 1.

Table 1: Share of Sample Companies in the Net Sales Revenue, by Category (2000-10)

\begin{tabular}{|c|c|c|c|c|c|c|c|c|c|c|c|}
\hline Category & 2000 & 2001 & 2002 & 2003 & 2004 & 2005 & 2006 & 2007 & 2008 & 2009 & 2010 \\
\hline $\begin{array}{l}\text { Share of Top } \\
50 \text { Companies }\end{array}$ & 58.19 & 63.13 & 67.84 & 68.89 & 68.38 & 66.81 & 67.28 & 68.23 & 68.01 & 67.24 & 69.75 \\
\hline \multicolumn{12}{|c|}{ Relative Shares of Different Categories of Firms in the Net Sales Revenue of Top 50 Companies } \\
\hline $\begin{array}{l}\text { Private Indian } \\
\text { Companies }\end{array}$ & 18.62 & 19.39 & 20.44 & 20.07 & 22.1 & 21.2 & 24.4 & 24.6 & 26.8 & 27.17 & 26.88 \\
\hline $\begin{array}{l}\text { Private Foreign } \\
\text { Companies }\end{array}$ & 19.59 & 15.88 & 14.48 & 15.42 & 13.8 & 15 & 13.6 & 11.4 & 10.6 & 10.55 & 10.99 \\
\hline $\begin{array}{l}\text { Group-Owned } \\
\text { Companies }\end{array}$ & 61.79 & 64.73 & 65.08 & 64.51 & 64.1 & 63.8 & 62.1 & 64 & 62.6 & 62.28 & 62.13 \\
\hline Aggregate & 100 & 100 & 100 & 100 & 100 & 100 & 100 & 100 & 100 & 100 & 100 \\
\hline \multicolumn{12}{|c|}{ Product-wise Relative Market Share of Different Categories of Products } \\
\hline Formulation & 67.96 & 67.60 & 66.47 & 67.80 & 66.79 & 66.83 & 63.35 & 64.55 & 62.45 & 60.60 & 58.40 \\
\hline Bulk & 5.91 & 6.28 & 7.74 & 7.36 & 7.68 & 7.43 & 7.95 & 7.66 & 7.84 & 8.10 & 9.19 \\
\hline Both & 26.13 & 26.11 & 25.79 & 24.84 & 25.54 & 25.75 & 28.70 & 27.80 & 29.71 & 31.30 & 32.42 \\
\hline Aggregate & 100 & 100 & 100 & 100 & 100 & 100 & 100 & 100 & 100 & 100 & 100 \\
\hline
\end{tabular}

Source: Calculated from PROWESS Database, CMIE 
As is evident from it, the share of these 50 companies has kept on rising over the past 10 years which points to the increasing dominance of large companies in the pharmaceutical industry. The structure is oligopoly in nature as few firms share the major portion of the market. The dominance of large companies was due to the high $R \& D$ requirement of the industry and it was also visible from increase in $R \& D$ intensity of the industry especially of large firms. The share of top four firms in sales revenue has remained stable around 20-25 percent in the product patent regime.

It would also be interesting to find out the relative share of these different categories of firms in the Total Net Sales Revenue generated by the Industry during different years (Table 1). Thus, share of these companies in the net sales revenue of the pharmaceutical industry has been steadily rising over the decade of 2000-10. Among all these companies, the group-owned companies share a big chunk of the market, distantly followed by the private Indian and foreign companies. It may further be pointed out here that these companies have also ventured into the production of bulk drugs as well during the decade under reference.

\subsection{The Variable Construct}

There are two types of DEA models viz., input-oriented and output-oriented. In an input-orientation model (input minimization), desired output is produced with minimum inputs. This model is preferred when inputs are more flexible than output. On the other hand, in an output-orientation model (output maximization), efforts are made to maximize the output with input level held fixed. The choice of the model depends on the available flexibility either with the inputs or outputs (Ramanathan, 2003; Coelliet al., 1998). Most of the inputs are flexible and can be changed according to the requirements. Nevertheless, the output variable may not have such flexibility as inputs variables have, as it is dependent on many external factors such as demand, exports etc., which are beyond the control of the firms. This study, therefore, applies the input-orientated DEA models.

The pharmaceutical industry is characterized by low fixed asset intensity and high working capital intensity (ICRA, 2002) with the material cost, manpower cost, marketing and selling cost and capital usage cost constituting the four major cost elements, accounting for close to $80 \%$ of the operating income. The following inputs and output variables, therefore, have been considered for the purpose of this study.

\subsubsection{Inputs and Output}

- Raw Material Cost (RM): It includes the cost of all raw materials, spares and packaging.

- Salary and Wages (SW) representing Employment Cost or Factor Payment to Human Capital Employed: It includes total annual expenses incurred by a firm on all employees, including management. These expenses also take account of payment of bonus, contribution to employee's provident fund and staff welfare related expenses. 
- Advertising and Marketing (AM) Cost:It includes the cost of advertising, marketing, distribution, travel and communication. It would include wages and salaries of their marketing executives and sales representatives, who are largely in the charge of promoting sales of the firm in the market. This includes the expenditure of the firm in encouraging the sales of the product as there is cut throat competition in this industry. The prescription drugs can be advertised through medical and trade journals or magazine, distribution of free samples and other materials. In some cases this cost is very substantial part of the total cost of production.

- Capital Usage Cost (CUC):It includes rent, interest, depreciation, repairs and maintenance of plant and machinery. It is used as proxy variable for capital.

Figure 2 shows that the ratio of raw material cost has remained around 50 percent of total cost. The share of capital cost has declined over a period and it is around $1 / 4^{\text {th }}$ of the TC. There is significant share of marketing and advertisement expenditure of around 10 percent in total cost due to the emphasis of firms on sales of formulations.

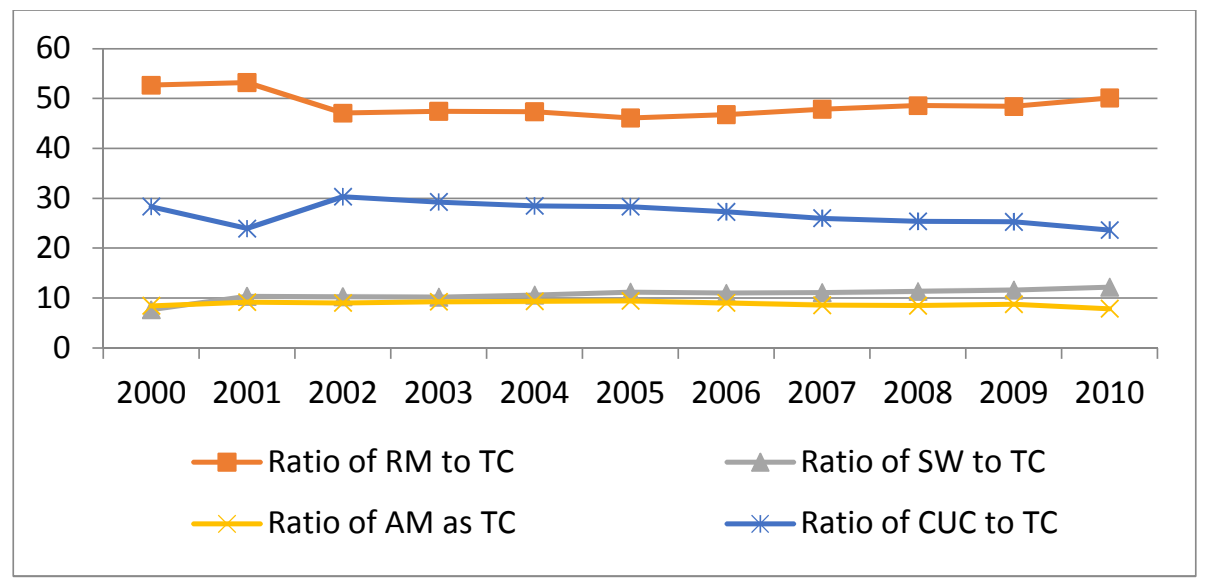

Figure 2: Trend in the Ratio of Inputs Cost to Total Cost

Source: Authors' computation based on CMIE Prowess database.

- Net Sales Revenue (NS):It is the amount of sales generated by a company after the deduction of returns, allowances for damaged or missing goods and any discounts allowed.In case of Indian pharmaceutical industry, a fair number of studies (Pannu et.al. 2011; Saranga and Phani, 2009) have made use of net sales revenue to examine the performance of the IPI.

The inputs selected ensure comparability within the sample of 50 firms. Descriptive statistics related to inputs and outputs are presented in Table 2. As is evident from the table, the mean sales revenue for the Group-Owned Firms is highest with a relatively high standard deviation. This suggests that there is a wide difference among this category of firms. Although the sales revenue of the Private Foreign 
Firms is higher than that of Private Indian Firms, yet both of them appear to be way behind the Group-Owned Firms. This is also evident from the fact that the average sales revenues for Private Indian and Foreign firms are well below the average sales revenue for the entire sample as such. Thus in terms of size, as judged by the net sales revenue, Group-Owned companies are much larger, followed by Private Foreign and Indian companies. The fact, that the sample comprises a wide variation in terms of size across the companies and groups, is further corroborated by the minimum and maximum values for net sales revenue for the entire sample as well as for all the three categories of firms. In regard of inputs, especially A\&M costs, high difference appears to be persisting among the Private Indian and GroupOwned Firms, as suggested by the high values of standard deviation for these categories of firms. It implies that there is a wide variation in terms of market aggression among the companies. There does not appear to be much difference in $A \& M$ costs across the category of Private Foreign Firms. This is further highlighted by the differences in the maximum and minimum net sales revenue.

Table 2: Descriptive Statistics of Inputs and Output (Rs. Mil. in 2010-11)

\begin{tabular}{|c|c|c|c|c|c|c|c|c|}
\hline \multirow[t]{2}{*}{ Variables } & \multicolumn{4}{|c|}{ Mean (Std. Dev.) } & \multicolumn{4}{|c|}{ Maximum(Minimum) } \\
\hline & $\begin{array}{l}\text { Private } \\
\text { Indian } \\
\text { Firms }\end{array}$ & $\begin{array}{c}\text { Private } \\
\text { Foreign } \\
\text { Firms }\end{array}$ & $\begin{array}{c}\text { Group- } \\
\text { Owned } \\
\text { Firms }\end{array}$ & $\begin{array}{c}\text { All } \\
\text { Sample }\end{array}$ & $\begin{array}{c}\text { Private } \\
\text { Indian } \\
\text { Firms } \\
\end{array}$ & \begin{tabular}{|c|c} 
Private \\
Foreign \\
Firms
\end{tabular} & $\begin{array}{c}\text { Group- } \\
\text { Owned } \\
\text { Firms }\end{array}$ & $\begin{array}{c}\text { All } \\
\text { Sample }\end{array}$ \\
\hline $\begin{array}{l}\text { Net Sales } \\
\text { Revenue }\end{array}$ & $\begin{array}{l}8842.51 \\
(5412.7)\end{array}$ & $\begin{array}{c}10168.69 \\
(6467.2)\end{array}$ & $\begin{array}{l}17973.23 \\
(16038.8)\end{array}$ & $\begin{array}{l}13045.69 \\
(12123.6)\end{array}$ & $\begin{array}{l}27117.7 \\
(3119.3)\end{array}$ & $\begin{array}{l}19703.5 \\
(4052.2)\end{array}$ & \begin{tabular}{|l|}
56786.2 \\
$(3135.7)$
\end{tabular} & $\begin{array}{l}56786.2 \\
(3119.3)\end{array}$ \\
\hline $\begin{array}{l}\text { Raw Material } \\
\text { Cost }\end{array}$ & $\begin{array}{l}3909.94 \\
(2798.5)\end{array}$ & $\begin{array}{l}2404.97 \\
(3730.3) \\
\end{array}$ & $\begin{array}{l}5752.76 \\
(5095.9)\end{array}$ & $\begin{array}{l}4510.08 \\
(4184.5)\end{array}$ & $\begin{array}{c}11028.1 \\
(960.5) \\
\end{array}$ & $\begin{array}{l}10576 \\
(172.6)\end{array}$ & $\begin{array}{c}17627.9 \\
(736.2)\end{array}$ & $\begin{array}{r}17627.9 \\
(172.6)\end{array}$ \\
\hline $\begin{array}{l}\text { Salaries \& } \\
\text { Wages Cost }\end{array}$ & $\begin{array}{l}585.84 \\
(573.5)\end{array}$ & $\begin{array}{l}897.63 \\
(477.1)\end{array}$ & $\begin{array}{l}1630.95 \\
(1546.4)\end{array}$ & $\begin{array}{l}1089.34 \\
(1196.9)\end{array}$ & $\begin{array}{l}2702.2 \\
(114.1)\end{array}$ & $\begin{array}{l}1880.5 \\
(478.1)\end{array}$ & $\begin{array}{l}6478.8 \\
(144.9)\end{array}$ & $\begin{array}{l}6478.8 \\
(114.1)\end{array}$ \\
\hline $\begin{array}{l}\text { Advertisement \& } \\
\text { Marketing Cost }\end{array}$ & $\begin{array}{l}415.64 \\
(580.5)\end{array}$ & $\begin{array}{c}516.46 \\
(298.59)\end{array}$ & $\begin{array}{c}1138.93 \\
(1121.08)\end{array}$ & $\begin{array}{c}748.002 \\
(900.4) \\
\end{array}$ & $\begin{array}{c}2022.1 \\
(23.3) \\
\end{array}$ & $\begin{array}{l}1162.6 \\
(279.3)\end{array}$ & $\begin{array}{c}3495.5 \\
(52.0) \\
\end{array}$ & $\begin{array}{l}3495.5 \\
(23.3) \\
\end{array}$ \\
\hline $\begin{array}{l}\text { Capital Usage } \\
\text { Cost }\end{array}$ & $\begin{array}{l}394.74 \\
(392.4)\end{array}$ & $\begin{array}{l}313.57 \\
(190.3)\end{array}$ & $\begin{array}{l}714.91 \\
(655.5)\end{array}$ & $\begin{array}{l}524.25 \\
(530.3)\end{array}$ & $\begin{array}{l}1517.2 \\
(50.9) \\
\end{array}$ & $\begin{array}{c}623.7 \\
(126.8)\end{array}$ & $\begin{array}{l}2448.0 \\
(135.2)\end{array}$ & $\begin{array}{c}2448.0 \\
(50.9) \\
\end{array}$ \\
\hline
\end{tabular}

Source: Calculated from Prowess Database of CMIE

The values of correlation coefficients from the inputs and output of all the sample firms show that the output variable has statistically significant correlation with the inputs. In order to test the validity of the selected variables, adjusted $\mathrm{R}^{2}$ and $\mathrm{F}$ statistics are calculated which are presented in Table 3. These estimates are based on multiple regression analysis with Net Sales Revenue as a dependent variable and raw material, salaries and wages, advertising and marketing expenditure and capital usage cost as independent variables.

\section{Table 3: Adjusted $\mathrm{R}^{2}$ and F-statistics (2010-11)}

\begin{tabular}{|l|c|c|c|c|c|c|}
\hline Estimates & $\mathbf{R}^{\mathbf{2}}$ & Adjusted $\mathbf{R}^{\mathbf{2}}$ & Std. Error & F-Statistics & Sig. & Df \\
\hline Results & 0.956 & 0.952 & 2650.04 & 245.138 & 0.000 & 45 \\
\hline
\end{tabular}

Notes: Independent variables- RM, SW, AM and CUC, Dependent variable: NS 
The value of adjusted R2 suggests that the four input variables together explain 95.2 percent of variations in net sales revenue. The F-statistics is found to be statistically significant at 1 percent. These two tests suggest that there exists a best-fit between explanatory and explained variables.

\section{Empirical Results and Discussions}

\subsection{Technical Efficiency Analysis}

Out of 50 firms, 9 firms are found to be overall technically efficient (OTE), and 19 firms are pure technically efficient $(B C C$ score $=1$ ) i.e., these firms can reduce their excess inputs being utilised while maintaining the same level of output,whereas remaining 31 firms are found to be relatively inefficient (BCC score $<1)$. These nine OTE efficient firms comprise: 4 Private Indian firms (Ankur Drugs \& Pharma Ltd., Arch Pharma Labs Ltd., Divi'S Laboratories Ltd., and Twilight Litaka Pharma Ltd); 3 Private Foreign firms (Abbott India Ltd, Glaxosmithkline, and Novartis India Ltd); and 2 Group Owned companies (Aarti Drugs Ltd, and Indoco Remedies Ltd.). Pure Technical Efficiency (PTE) measures how efficiently inputs are converted into output(s), irrespective of size of the firms. The average of PTE is worked out to be 0.858 , which means that given the scale of operation, on an average, firms can reduce their inputs by 14.2 percent of the observed levels without affecting output levels. Scale efficiency (SE) measures the impact of scale-size on the efficiency of a firm. It is measured as a ratio of CCR efficiency to BCC efficiency. If the value of SE score is one, then the firm is apparently operating at optimal scale. If the value is less than one, then it appears to be either too small or too big relative to its optimum scale-size. The results show that out of 50 firms, 9 firms are scale efficient, while remaining 41 firms are scale inefficient. The average of SE is 0.871 , which indicates that an average firm may be able to decrease its inputs by 12.9 percent beyond its best practice targets under VRS, if it were to operate at CRS. From returns to scale, it is found that 9 firms ( 18 per cent) are in the stage of CRS; 15 firms ( 30 percent) are in the stage of IRS; and remaining 26 firms (52 percent) are operating in the domain of DRS. Thus, most of the large Indian pharmaceutical firms operated under DRS during 2010-11, which means that their efficiency can be increased by decreasing their size of operation.

\subsection{Ranking Based on Super-Efficiency Scores}

Basic CCR and BCC models of efficiency do not give us the ranking of the firms as all efficient DMUs are assigned the efficiency score of unity. The modified version of DEA, developed by Anderson and Peterson (1993) gives the ranking of the efficient firms based on their super efficiency scores, which are similar in case of inefficient firms.

Table 4 provides OTE, PTE, SE, super-efficiency scores based on VRS assumption and also super efficiency (CRS) and ranking of the firms based on different scales. From Table 4, first in the case of VRS assumption, Firm 8 (Aurobindo Pharma Ltd.) emerges as the top firm followed in accordance of their ranking by Firm 44 
(Twilight Litaka Pharma Ltd.), Firm 2 (Abbott India Ltd.), Firm 5 (Ankur Drugs \& Ltd.), Firm 29 (Natco Pharma Ltd.) and Firm 31 (Novartis India Ltd.). CiplaLtd.s' super efficiency score was found to be infeasible; therefore, it was not included in the ranking. In case of VRS super efficiency model, there is a possibility of infeasibility of the related linear program (Seiford and Zhu 1998, Zhu, 2001; Yao, 2003). On the other hand, when we take the case of CRS assumption, then Twilight Litaka Pharma Ltd. was found to the top firm, as it has the highest super efficiency score followed in accordance of their CRS ranking by Firm 5 (Ankur Drugs and Itd.), Firm 2 (Abbott India Ltd.), Firm 31 (Novartis India Ltd.) and Firm 12 (Divis' Lab.Ltd.). The rankings were found to be different at both the scales of operations. It may be mentioned here that Twilight is the manufacturer of several brands for major national and multinational pharmaceutical companies in India for more than three decades. It has well established distribution network across India and also exports to over 40 countries. Abbott India Ltd. is one of India's fastest growing pharmaceutical companies and a subsidiary of Abbott laboratories enjoys strong brand equity in multiple therapeutic categories. Ankur Drugs Ltd. continues to maintain a leadership position in the domestic contract manufacturing sphere for pharmaceutical industry and has made significant inroads in its area of operation. It is among the top five pharma contract manufacturing company in India. Novartis India Ltd is the world's second largest pharmaceutical company in 2011. Natco is one of the few Indian companies to venture into New Drug Discovery.

Table 4: Technical Efficiency and Super-Efficiency Scores for IP Firms

\begin{tabular}{|c|l|c|c|c|c|c|c|c|c|}
\hline S.No. & \multicolumn{1}{|c|}{ Firm's Name } & OTE & PTE & SE & $\begin{array}{c}\text { Super } \\
\text { Efficiency } \\
\text { Scores VRS }\end{array}$ & $\begin{array}{c}\text { Super } \\
\text { Efficiency } \\
\text { CRS }\end{array}$ & $\begin{array}{c}\text { Ranks } \\
\text { CRS }\end{array}$ & $\begin{array}{c}\text { Ranks } \\
\text { VRS }\end{array}$ & RTS \\
\hline 1 & Aarti Drugs Ltd. & 1 & 1 & 1 & 1.25 & 1.05 & 8 & 12 & CRS \\
\hline 2 & Abbott India Ltd. & 1 & 1 & 1 & 1.98 & 1.89 & 3 & 3 & CRS \\
\hline 3 & Ajanta Pharma Ltd. & 0.55 & 0.84 & 0.65 & 0.84 & 0.55 & 43 & 30 & IRS \\
\hline 4 & Alembic Ltd. & 0.46 & 0.5 & 0.92 & 0.50 & 0.46 & 48 & 49 & DRS \\
\hline 5 & Ankur Drugs Ltd. & 1 & 1 & 1 & 1.98 & 1.93 & 2 & 4 & CRS \\
\hline 6 & Arch Pharmalabs Ltd. & 1 & 1 & 1 & 1.02 & 1.01 & 9 & 17 & CRS \\
\hline 7 & Astrazeneca Pharma India Ltd. & 0.64 & 1 & 0.64 & 1.31 & 0.67 & 30 & 8 & IRS \\
\hline 8 & Aurobindo Pharma Ltd. & 0.9 & 1 & 0.9 & 3.29 & 0.90 & 12 & 1 & DRS \\
\hline 9 & Aventis Pharma Ltd. & 0.52 & 0.56 & 0.91 & 0.60 & 0.57 & 42 & 45 & DRS \\
\hline 10 & Cadila Healthcare Ltd. & 0.43 & 0.66 & 0.65 & 0.66 & 0.43 & 49 & 41 & DRS \\
\hline 11 & Cipla Ltd. & 0.92 & 1 & 0.92 & Infeasible & 0.92 & 10 & & DRS \\
\hline 12 & Divi'S Laboratories Ltd. & 1 & 1 & 1 & 1.28 & 1.27 & 5 & 10 & CRS \\
\hline 13 & Dr. Reddy'S Laboratories Ltd. & 0.62 & 1 & 0.62 & 1.04 & 0.62 & 36 & 16 & DRS \\
\hline 14 & Elder Pharmaceuticals Ltd. & 0.6 & 0.66 & 0.91 & 0.66 & 0.61 & 37 & 42 & IRS \\
\hline 15 & F D C Ltd. & 0.75 & 0.82 & 0.92 & 0.84 & 0.77 & 26 & 31 & IRS \\
\hline 16 & Glaxosmithkline Pharma Ltd. & 0.94 & 1 & 0.94 & 1.66 & 1.13 & 7 & 7 & DRS \\
\hline 17 & Glenmark Pharmaceuticals Ltd. & 0.61 & 0.63 & 0.98 & 0.63 & 0.61 & 38 & 44 & DRS \\
\hline 18 & Granules India Ltd. & 0.65 & 0.8 & 0.81 & 0.80 & 0.65 & 32 & 35 & IRS \\
\hline 19 & Hetero Drugs Ltd. & 0.81 & 1 & 0.81 & 1.13 & 0.81 & 19 & 14 & DRS \\
\hline
\end{tabular}


Efficiency and Ranking of Indian Pharmaceutical Industry: Does Type of Ownership Matter?

Table 4 (cont.): Technical Efficiency and Super-Efficiency Scores for IP Firms

\begin{tabular}{|c|c|c|c|c|c|c|c|c|c|}
\hline S.No. & Firm's Name & OTE & PTE & SE & \begin{tabular}{|c|} 
Super \\
Efficiency \\
Scores VRS \\
\end{tabular} & $\begin{array}{c}\text { Super } \\
\text { Efficiency } \\
\text { CRS }\end{array}$ & $\begin{array}{c}\text { Ranks } \\
\text { CRS }\end{array}$ & $\begin{array}{c}\text { Ranks } \\
\text { VRS }\end{array}$ & RTS \\
\hline 20 & Indoco Remedies Ltd. & 1 & 1 & 1 & 1.21 & 1.18 & 6 & 13 & CRS \\
\hline 21 & Ind-Swift Laboratories Ltd. & 0.77 & 0.78 & 0.99 & 0.81 & 0.77 & 25 & 34 & DRS \\
\hline 22 & Ind-Swift Ltd. & 0.59 & 0.88 & 0.68 & 0.88 & 0.59 & 40 & 27 & IRS \\
\hline 23 & Intas Pharmaceuticals Ltd. & 1 & 1 & 1 & 0.88 & 0.83 & 18 & 25 & CRS \\
\hline 24 & Ipca Laboratories Ltd. & 0.6 & 0.73 & 0.81 & 0.73 & 0.60 & 39 & 39 & DRS \\
\hline 25 & J B Chemicals \& Pharma Ltd. & 0.51 & 0.52 & 0.98 & 0.52 & 0.51 & 46 & 47 & IRS \\
\hline 26 & Lupin Ltd. & 0.66 & 0.96 & 0.68 & 0.96 & 0.66 & 31 & 19 & DRS \\
\hline 27 & Matrix Laboratories Ltd. & 0.8 & 0.96 & 0.83 & 0.96 & 0.80 & 21 & 20 & DRS \\
\hline 28 & Merck Ltd. & 0.64 & 0.85 & 0.76 & 0.88 & 0.65 & 33 & 28 & IRS \\
\hline 29 & Natco Pharma Ltd. & 0.86 & 1 & 0.86 & 1.94 & 0.85 & 15 & 5 & IRS \\
\hline 30 & Nectar Lifesciences Ltd. & 0.87 & 0.88 & 0.99 & 0.88 & 0.87 & 13 & 26 & DRS \\
\hline 31 & Novartis India Ltd. & 1 & 1 & 1 & 1.86 & 1.53 & 4 & 6 & CRS \\
\hline 32 & OrchidPharmaceuticals & 0.79 & 0.95 & 0.83 & 0.95 & 0.79 & 22 & 21 & DRS \\
\hline 33 & Panacea Biotec Ltd. & 0.51 & 0.52 & 0.99 & 0.52 & 0.51 & 45 & 48 & DRS \\
\hline 34 & Parenteral DrugsLtd. & 0.83 & 1 & 0.83 & 1.30 & 0.83 & 17 & 9 & IRS \\
\hline 35 & Pfizer Ltd. & 0.53 & 0.55 & 0.96 & 0.55 & 0.53 & 44 & 46 & DRS \\
\hline 36 & Piramal Healthcare Ltd. & 0.58 & 0.9 & 0.64 & 0.90 & 0.58 & 41 & 23 & DRS \\
\hline 37 & Plethico Pharma Ltd. & 0.83 & 0.95 & 0.87 & 1.02 & 0.87 & 14 & 18 & IRS \\
\hline 38 & Ranbaxy Laboratories Ltd. & 0.43 & 0.89 & 0.49 & 0.89 & 0.43 & 50 & 24 & DRS \\
\hline 39 & Shasun Pharmaceuticals Ltd. & 0.81 & 0.81 & 1 & 0.81 & 0.81 & 20 & 33 & $\mathrm{IRS}$ \\
\hline 40 & Strides Arcolab Ltd. & 0.78 & 0.79 & 0.99 & 0.79 & 0.78 & 24 & 36 & DRS \\
\hline 41 & Sun Pharmaceutical Inds. Ltd. & 0.68 & 0.72 & 0.94 & 0.75 & 0.68 & 29 & 37 & DRS \\
\hline 42 & Surya Pharmaceutical Ltd. & 0.92 & 1 & 0.92 & 1.09 & 0.92 & 11 & 15 & DRS \\
\hline 43 & Torrent Pharmaceuticals Ltd. & 0.6 & 0.68 & 0.88 & 0.72 & 0.63 & 35 & 40 & DRS \\
\hline 44 & Twilight Litaka Pharma Ltd. & 1 & 1 & 1 & 2.52 & 2.02 & 1 & 2 & CRS \\
\hline 45 & U S V Ltd. & 0.79 & 0.81 & 0.97 & 0.81 & 0.79 & 23 & 32 & DRS \\
\hline 46 & Unichem Laboratories Ltd. & 0.64 & 0.66 & 0.97 & 0.66 & 0.64 & 34 & 43 & IRS \\
\hline 47 & Unimark Remedies Ltd. & 0.84 & 0.85 & 0.99 & 0.85 & 0.84 & 16 & 29 & DRS \\
\hline 48 & Venus Remedies Ltd. & 0.76 & 1 & 0.76 & 1.25 & 0.76 & 27 & 11 & IRS \\
\hline 49 & Wanbury Ltd. & 0.46 & 0.74 & 0.62 & 0.74 & 0.46 & 47 & 38 & IRS \\
\hline 50 & Wockhardt Ltd. & \begin{tabular}{|l|}
0.7 \\
\end{tabular} & 0.91 & 0.77 & 0.91 & 0.70 & 28 & 22 & DRS \\
\hline Mean & & 0.74 & 0.86 & 0.87 & & & & & \\
\hline
\end{tabular}

\subsection{Classification of Firms}

I. Most Inefficient firms: This category includes those firms which have OTE score below the first quartile (0.657). These firms are Alembic Ltd. , Aventis Pharma Ltd., Elder Pharmaceuticals Ltd., Glenmark Pharmaceuticals Ltd., J.B. Chemicals \& Pharmaceuticals Ltd. , Panacea Biotec Ltd., Pfizer Ltd.

II. Below average firms: In below average category, a firm whose OTE score lies between first (0.657) and second quartile (0.802). These firms are Cadila Healthcare Ltd., Ind-swift Laboratories, Ipca Laboratories Ltd., Strides Arcolab 
Ltd., Sun Pharmaceutical Ltd., Torrent Pharmaceuticals Ltd., Unichem Laboratories Ltd., and Wanbury Ltd. .

III. Above average firms: The above average category consists of the firms wherein OTE score lies between median (0.802) and third quartile (0.880). These firms are Ajanta Pharma Ltd., FDC Ltd., Granules India Ltd, Ind-Swift Ltd, Merck Ltd, Shasun Pharmaceuticals Ltd., USV Ltd., and Unimark Remedies Ltd.

IV. Marginally inefficient firms: This category includes the firms with OTE score more than third quartile $(0.880)$ but less than one. These firms are Lupin Ltd, Matrix Laboratories Ltd, NectorLifesciences Ltd, Orchid Chemicals \& Pharmaceuticals, Piramal Healthcare Ltd, Plethico Pharmaceuticals Ltd, Ranbaxy Laboratories Ltd, and Wockhardt Ltd.

V. Efficient firms: In this category, firms with OTE score equal to one are included. These are: Aarti Drugs Ltd., Abbott India Ltd., Ankur Drugs Ltd., Arch Pharmalabs Ltd., Divi's Laboratories Ltd., Indoco Remedies Ltd., Intas Pharmaceuticals, Novartis India Ltd., and Twilight Litika Pharma Ltd.

\subsection{Efficiency According to Ownership}

As is evident from Table 5, in the overall sample of 50 firms, 21, 7, 22 are Private Indian (PI), Private Foreign (PF) and group- owned firms (GO), respectively. These firms have been classified by the ownership with the presumption that different ownership have different efficiency patterns and that sometime their impacts could even overshadow the operational efficiency of the firms concerned, despite the possibility that intense competition in the market may act as strong leveler of performance. It is observed that mean OTE scores of PI and PF is higher than GO firms. Mean OTE scores for the PI and PF firms stood at 0.809 and 0.806 respectively, whereas it was found to be 0.665 for GO firms. The GO firms have shown the least OTE (0.665) and PTE (0.799) scores among all categories of firms. Although, it is generally perceived that foreign companies have better efficiency on account of their superior technical and managerial capabilities (Caves, 1992), the estimates obtained here appear to be not corroborating the same. The PTE scores of PI and PF firms are similar and GO firms have the least PTE scores. The most plausible reason for the PI and PF to have a higher degree of efficiency is that Private Indian Firms have to operate in an intensely competitive environment for the markets and the resources for survival and growth and PF firms have superior technology, high R\&D expenditure and better managerial practices (Mazumdar et al., 2009). On the other hand, groupowned companies may have options to fall back upon associate companies at least for the resources if not for the markets. The key driving forces behind the high efficiency of Private Indian companies are the aggressive new product introductions and a greater importance on generic exports of bulk and formulation drugs. Thus, the business operation environment on account of different ownership pattern could also affect efficiency of the firms in the same industry. 
Table 5: Ownership-Wise Descriptive Statistics of OTE, PTE, SE and RTS

\begin{tabular}{|l|c|c|c|c|c|c|c|c|c|}
\hline \multirow{2}{*}{ Particulars } & \multicolumn{3}{|c|}{ Private Indian } & \multicolumn{3}{c|}{ Private Foreign } & \multicolumn{3}{c|}{ Group-owned } \\
\cline { 2 - 11 } & OTE & PTE & SE & OTE & PTE & SE & OTE & PTE & SE \\
\hline Mean & 0.809 & 0.901 & 0.898 & 0.806 & 0.912 & 0.886 & 0.665 & 0.799 & 0.841 \\
\hline Minimum & 0.462 & 0.658 & 0.623 & 0.532 & 0.553 & 0.671 & 0.431 & 0.498 & 0.485 \\
\hline Maximum & 1 & 1 & 1 & 1 & 1 & 1 & 1 & 1 & 1 \\
\hline N & 21 & 21 & 21 & 7 & 7 & 7 & 22 & 22 & 22 \\
\hline Std. Dev & 0.142 & 0.105 & 0.17 & 0.196 & 0.165 & 0.139 & 0.174 & 0.177 & 0.149 \\
\hline No. of efficient firms & 4 & 9 & 4 & 3 & 4 & 3 & 2 & 6 & 2 \\
\hline \multirow{2}{*}{ No. of firms on RTS } & CRS & IRS & DRS & CRS & IRS & DRS & CRS & IRS & DRS \\
\cline { 2 - 10 } & 4 & 8 & 9 & 3 & 2 & 2 & 2 & 5 & 15 \\
\hline
\end{tabular}

The result summed up in Table 5 indicates that Group-Owned Firms have the scope for 33.5 percent reduction in inputs without altering the output in case of CRS technology and 20.1 percent in case of VRS technology. Similarly, in case of PTE scores also, PI and PF have highest mean efficiency of around 90 and 91 percent, whereas GO firms have 84 percent efficiency. In PI category, 4 firms are OTE efficient; 9 firms are PTE efficient; and 4 firms are scale efficient. Private Foreign and Private Indian firms are found to be more efficient as compared to their groupowned counterparts.

\subsection{Slacks Analysis According to Ownership}

From Table 6, it is comprehensible that maximum slacks have been observed in Private Indian and Group-owned firms as compared to Private Foreign firms. Foreign firms are better resource-endowed than domestic firms in terms of capital, technology and managerial practices. The foreign firms have brand name, reputation, better engineering skills, marketing and advertisement experience (Hymer, 1976). The input-output balance among foreign firms is better than domestic firms and foreign firms bring in technology utilization capabilities into another country (Caves, 1992; Pannu et at., 2011). In case of raw material input there has not been any slacks, which shows the efficient utilisation of raw material in the Indian D\&P industry. The maximum slack is observed in advertisement and marketing cost. The significant slacks are also observed in salary \& wages and capital usage cost. The highest slack is estimated in GO firms in case of salary and wages. Nevertheless, the possibility of reduction in the slacks pertaining to salaries \& wages is far more difficult to realise due to stringent labour laws (Dutta Chaudhuri, 1990). The output has shown slack in only one firm which is a private Indian firm. Private Foreign firms are having least slacks in inputs and output.

The target values of inputs and output and also their reduction in inputs and addition in output in percentage form is shown in Table 7. In case of raw material cost, the target mean values for PI, PF and GO firms are Rs. 2530.85, Rs. 3959.54 and Rs. 3546.96 million, respectively and subsequently their reduction in percentage is $17.4(\mathrm{PI}), 20.36(\mathrm{PF})$ and $27.54(\mathrm{GO})$. Similarly these results are shown for other inputs and also output. As slacks were found to be highest in PI and GO 
firms, the results of percentage reduction in inputs have shown highest in these categories. The advertisement \& marketing expenditure needs the special focus so that firms may efficiently utilise the inputs and improve their efficiency scores.

Table 6: Ownership-Wise Slack Estimation (in Million Rs.)

\begin{tabular}{|c|c|c|c|}
\hline Input and output & Mean & Minimum & Maximum \\
\hline \multicolumn{5}{|c|}{ Panel (A) : Total sample of 50 firms } \\
\hline RM & 0 & 0 & 0 \\
\hline SW & 62.227 & 0 & 1669.856 \\
\hline AM & 105.725 & 0 & 1140.865 \\
\hline CC & 55.278 & 0 & 1051.202 \\
\hline NS & 10.366 & 0 & 518.301 \\
\hline \multicolumn{5}{|c|}{ Panel (B) : Sample of 22 Group-owned Firms } \\
\hline RM & 0 & 0 & 0 \\
\hline SW & 117.18 & 0 & 1669.86 \\
\hline AM & 127.77 & 0 & 1055.74 \\
\hline CC & 42.23 & 0 & 325.71 \\
\hline NS & 0 & 0 & 0 \\
\hline \multicolumn{5}{|c|}{ Panel (C) : Sample of 7 Private Foreign Firms } \\
\hline RM & 0 & 0 & 0 \\
\hline SW & 0 & 0 & 0 \\
\hline AM & 0.34 & 0 & 136.04 \\
\hline CC & 19.43 & 0 & 0 \\
\hline NS & 0 & 0 & 0 \\
\hline \multicolumn{5}{|c|}{ Panel (D) : Sample of 21 Private Indian Firms } \\
\hline RM & 0 & 0 & 1140.87 \\
\hline SW & 25.4 & 0 & 1051.2 \\
\hline AM & 117.76 & 0 & 518.3 \\
\hline CC & 80.9 & 0 & 0 \\
\hline NS & 24.68 & 0 & 0 \\
\hline \multicolumn{5}{|c|}{0} \\
\hline
\end{tabular}

Table 7: Target value with Reduction in Inputs and Addition to Output

\begin{tabular}{|l|c|c|c|c|c|c|}
\hline \multirow{2}{*}{$\begin{array}{l}\text { Inputs and } \\
\text { output }\end{array}$} & \multicolumn{3}{|c|}{$\begin{array}{c}\text { Target values of Inputs and } \\
\text { Output }\end{array}$} & \multicolumn{2}{|c|}{$\begin{array}{c}\text { Reduction in Inputs and Addition } \\
\text { in Output (\%) }\end{array}$} \\
\cline { 2 - 7 } & PI & PF & GO & PI & PF & GO \\
\hline NS & 9362.2 & 10873.73 & 15036.31 & 1.1 & 0 & 0 \\
\hline RM & 2530.85 & 3959.54 & 3546.96 & 17.4 & 20.36 & 27.54 \\
\hline SW & 609.9 & 637.34 & 1085.62 & 22.09 & 20.36 & 31.72 \\
\hline AM & 305.37 & 309.07 & 702.27 & 35.87 & 20.59 & 42.64 \\
\hline CC & 282.86 & 276.94 & 432.52 & 27.37 & 27.63 & 33.64 \\
\hline
\end{tabular}

Marketing of pharmaceutical products in India is very challenging and tough because Indian pharmaceutical market is highly fragmented with over 60,000 brands battling for share in the market. The leading pharmaceutical firms spend a significant amount of their revenue on sales promotion, training of medical 
representatives and building of brands. The company should identify an optimum sales and marketing mix so as to yield desired profits, which will help in growth of the business. Generally, expenditure on advertisement \& marketing exceeds R\&D expenditure due to high expenditure of the firm in encouraging the sales of the product as there is cut throat competition in this industry. A study by Gagnon and Lexchin (2008) finds that pharmaceutical companies generally spend almost twice as much as on sales promotion as they do on R\&D expenditure.

\section{Conclusions and Policy Implications}

This paper measures the technical efficiency, input-output slacks, and ranking of individual firms as per the ownership type in order to find out if there are significant differences among the firms belonging to different types of ownership. From the analysis, it is found that 9 firms are overall technical efficient, and 19 firms are pure technical efficient, while the remaining firms are inefficient. The average of PTE is worked out to be 0.858 , which suggests that given the scale of operation, on an average, firms can reduce their inputs by 14.2 percent of their observed levels without affecting output levels. The results also show that 9 firms are scale efficient, while remaining $\mathbf{4 1}$ firms are scale inefficient. On the basis of super-efficiency scores, firms have been ranked. Aurobindo Pharma Ltd. (Firm 8) emerges as the top firm, while Alembic Ltd. (Firm 4) is found to be at the bottom in the ranking. From the classification of the firms on the basis of ownership, it is found that efficiency scores of Private Indian (PI) and Private Foreign (PF) are higher than GO (Group-owned) firms. The most possible reason for the PI and PF to have a higher degree of efficiency, could be that while Private Indian Firms have to operate in an intensely competitive environment for the markets and the resources for survival and growth, group-owned companies may have options to fall back upon associate companies at least for the resources, if not for the markets.

The slack analysis highlights that the Private Indian and Group-owned firms have maximum slacks, as compared to Private Foreign. Further, maximum slacks are observed in regard of advertisement \& marketing, along with noteworthy slacks in salary \& wages and capital usage inputs. Therefore, proper utilization of inputs may result in significant improvement in the efficiency of the firms and improve their efficiency. Interestingly, no slacks are found in case of raw material inputs. The private foreign firms, probably for their access to the latest production technology and best management practices, are observed to have least slacks in inputs and output and therefore are able to utilise the resources efficiently as compared to private Indian and group-owned firms.

This study, however, has certain limitations as it encompasses only large firms and limited to cross-sectional data, and therefore, needs to be generalized with caution. Additionally, there is a scope for analysing the efficiency and productivity trends especially after the modification of Indian Product Patent Act in 2005, which could be undertaken for further research. 


\section{References}

Agarwal, S. Yadav, S.P. and Singh. S.P. (2010). DEA based estimation of the technical efficiency of state transport undertakings in India. OPSEARCH, 47(3), 216-230. http://dx.doi.org/10.1007/s12597-011-0035-4

Andersen, P. \& Petersen, N.C. (1993). A procedure for ranking efficient units in data envelopment analysis. Management Science, 39(10), 1261-1264. http://dx.doi.org/10.1287/mnsc.39.10.1261 Banker, R.D., Charnes A., Cooper, W.W. (1984). Some models for the estimation of technical and scale inefficiencies in data envelopment analysis. Management Science, 30(9), 10781092.

http://dx.doi.org/10.1287/mnsc.30.9.1078

Bauer, P. W., Berger, A. N., Ferrier, G. D., \& Humphrey, D. B. (1998). Consistency conditions for regulatory analysis of financial institutions: a comparison of frontier efficiency methods. Journal of Economics and Business, 50(2), 85-114. http://dx.doi.org/10.1016/S0148-6195(97)00072-6

Bayyurt, N. and Duzu, G. (2008). Performance measurement of Turkish and Chinese manufacturing firms: a comparative analysis. Eurasian Journal of Business and Economics, 1 (2), 71-83.

Bhasa, M. P. (2006). Does ownership affect performance? Empirical evidence from the Indian pharmaceutical industry. Finance India, 20(3), 913-940.

Cambridge Consultants, (2013) India: Driving world pharmaceuticals by 2030 ? Accessed on June 18, 2014 from website: http://www.pharmaleaders.tv/wpcontent/uploads/2013/03/IND2012-DR-006_web-v0.1.pdf

Caves, R.E. (1992). Determinants of technical efficiency in Australia.In Richard E. Caves (eds.), Industrial Efficiency in Six Nations. Cambridge (Mass): MIT Press, 241-272.

Charnes, A., Cooper, W.W., Rhodes, E. (1978). Measuring the efficiency of decision making units. European Journal of Operational Research, 2, 429-441. http://dx.doi.org/10.1016/0377-2217(78)90138-8

Chaudhuri, K. and Das, S. (2006). WTO, the TRIPS and Indian pharmaceutical industry. Journal of Quantitative Economics, 4(1), 97-110.

Chaudhuri, S.(2005). The WTO and India's Pharmaceuticals Industry. Oxford University Press, New Delhi.

Coelli, T., Rao, D.S.P. and Battese, G. (1998). An Introduction to Efficiency and Productivity Analysis. Kluwar Academic Publishers, London, North Holland. http://dx.doi.org/10.1007/978-1-4615-5493-6

Cooper, W.W., Lawrence, M.S. and Tone, K. (2006) Introduction to Data Envelopment Analysis and its Uses. Springer, New York.

Corporate Catalyst India Pvt Ltd (2014) A Brief Report on Pharmaceutical Industry in India. New Delhi.

Doyle, J.R. and Green, R.H. (1994). Efficiency and cross-efficiency in DEA: derivatives meaning and uses. Journal of Operational Research Society, 45 (5), 567-578. http://dx.doi.org/10.1057/jors.1994.84

Dutta Chaudhuri, M., (1990). Background to the current debate on economic reforms: oil shocks, world trade and adjustment problems for the Indian economy. In: Guha, A. (Ed.), Economic Liberalization, Industrial Structure and Growth in India, Oxford University Press, New Delhi. 
Gagnon, M-A and Lexchin, J. (2008). The cost of pushing pills: A new estimate of pharmaceutical promotion expenditures in the United States. PLoS Medicine, 5(1): e1. http://dx.doi.org/10.1371/journal.pmed.0050001

Grace, C. (2004). The effect of changing intellectual property on pharmaceutical industry prospects in India and China. DFID Health Systems Resource Centre, 1-68.

Greene, W. (2007). The emergence of India's pharmaceutical industry and implications for the US generic drug market. US International Trade Commissin, Office of Economics.

Hamied, Y.K. (1993). Patents and the pharmaceutical industry: a review. Presentation at the International Conference on Patent Regime Proposed in the Uruguay Round, New Delhi, Cipla Ltd.

Hymer, S.H. (1976). The International Operations of National Firms: A Study of Direct Foreign Investment, The MIT Press, Cambridge, M.A.

ICRA (2002). The Indian Pharmaceutical Industry. ICRA Industry Watch Series, New Delhi.

Joshi, R.N. and Singh, S.P. (2008). Productivity growth and efficiency trends in the Indian textile industry. Journal of Textile Association, 68(6), 242-250.

Kaur, P. and Kaur, G. (2010). Impact of mergers on the cost efficiency of Indian commercial banks. Eurasian Journal of Business and Economics, 3 (5), 27-50. http://dx.doi.org/10.1108/17410400810904029

Kumar, S. and Arora, N. (2012). Evaluation of technical efficiency in Indian sugar industry: an application of full cumulative data envelopment analysis. Eurasian Journal of Business and Economics, 5 (9), 57-78.

Kumar, S. and Gulati, R. (2008). Evaluation of technical efficiency and ranking of public sector banks in India: an analysis from cross-sectional perspective. International Journal of Productivity and Performance Management, 57(7), 540-568.

Mahajan, V., Nauriyal, D.K. and Singh, S.P. (2014). Technical efficiency analysis of the Indian drug and pharmaceutical industry: A Non-parametric Approach, Benchmarking: An International Journal, 21(5), 734-755.

Majumdar, S.K. (1998). Slack in the state -owned enterprises: An evaluation of the impact of soft -budget constraints. International Journal of Industrial Organization, 16(3), 377 -94. http://dx.doi.org/10.1016/S0167-7187(96)01043-0

Mazumdar, M. and Rajeev, M. (2009). Comparing the efficiency and productivity of the Indian pharmaceutical firms: A Malmquist-Meta-Frontier approach. International Journal of Business and Economics, 8(2), 159-181.

Mazumdar, M., Rajeev, M., \& Ray, S. C. (2009). Output and Input Efficiency of Manufacturing Firms in India: A Case of the Indian Pharmaceutical Sector. Institute for Social and Economic Change.

Mishra, P. and Chandra, T. (2010). Mergers, acquisitions and firm's performance: Experience of Indian pharmaceutical industry. Eurasian Journal of Business and Economics, 3(5): 111-126.

Mogha, S.K., Yadav, S.P. and Singh, S.P. (2014). New slack model based efficiency assessment of public sector hospitals of Uttarakhand: State of India. International Journal of Systems Assurance Engineering and Management, 5(1): 32-42. http://dx.doi.org/10.1007/s13198013-0207-0

Nauriyal, D. K., \&Sahoo, D. (2008). The new IPR regime and Indian drug and pharmaceutical industry: An empirical analysis. In 3rd Annual Conference of the EPIP Association, Bern, Switzerland-Gurten Park/October (pp. 3-4). 
Ozcan, Y.A., (2008). Healthcare Benchmarking and Performance Evaluation: An Assessment Using Data Envelopment Analysis, Springer, New York. http://dx.doi.org/10.1007/978-0-38775448-2

Pannu, H.S., Kumar, U.D. and Farooquie, J.A. (2011). Efficiency and productivity analysis of Indian pharmaceutical industry using data envelopment analysis. International Journal of Operational Research, 10(1), 121-136. http://dx.doi.org/10.1504/IJOR.2011.037266

Ramanathan, R. (2003). An Introduction to Data Envelopment Analysis: A Tool for Performance Measurement. Sage Publising, New Delhi.

Saranga, H. (2007). Multiple objective data envelopment analysis as applied to the Indian Pharmaceutical Industry. Journal of the Operational Research Society, 58(11), 1480-1493. http://dx.doi.org/10.1057/palgrave.jors.2602280

Saranga, H., \& Banker, R. D. (2010). Productivity and technical changes in the Indian pharmaceutical industry. Journal of the operational research society,61(12), 1777-1788. http://dx.doi.org/10.1057/jors.2009.142

Saranga, H., \&Phani, B. V. (2009). Determinants of operational efficiencies in the Indian pharmaceutical industry. International transactions in operational research, 16(1), 109-130.

http://dx.doi.org/10.1111/j.1475-3995.2009.00668.x

Seiford, L.M. and Zhu, J. (1998). Stability regions for maintaining efficiency in data envelopment analysis.European Journal of Operational Research, 108, 127-39. http://dx.doi.org/10.1016/S0377-2217(97)00103-3

Shivdas, A.P. (2012). Resource Based View of Performance Measurement of Pharmaceutical Companies in India: Sales versus Efficiency, Amrita School of Business, Working Paper No.120.

Sinuany-Stern, Z. \& Friedman L. (1998). DEA and the discriminant analysis of ratios for ranking units. European Journal of Operations Research, 111, 470-478. http://dx.doi.org/10.1016/S0377-2217(97)00313-5

Sinuany-Stern, Z., Mehrez, A. and Barboy, A. (1994). Academic departments efficiency via DEA. Computer and O.R. 21 (5), 543-556. http://dx.doi.org/10.1016/0305-0548(94)90103-1

Sueyoshi, T. \&Kirihara A. (1998). Efficiency measurement and strategic classification of Japanese banking institutes. International Journal of Systems Science, 29, 1249-1263. http://dx.doi.org/10.1080/00207729808929613

Tone, K. (2002). A slacks-based measure of super-efficiency in data Envelopment Analysis. European Journal of Operational Research, 143, 32-41. http://dx.doi.org/10.1016/S03772217(01)00324-1

Tyagi, S., Mahajan, V. and Nauriyal, D.K. (2014). Innovations in Indian drug and pharmaceutical industry: Have they impacted exports?. Journal of Intellectual Property Rights, 19 (July), 243-252

Yao, C. (2003). Measuring super-efficiency in DEA in presence of infeasibility. European Journal of Operational research, 161(2), 429-444.

Yawe, B. (2010). Hospital performance evaluation in Uganda: a super-efficiency data envelope analysis model. Zambia Social Science Journal, 1(1): 79-105

Zhu, J. (2001). Super-efficiency and DEA sensitivity analysis. European Journal of Operational Research, 129, 443-455. http://dx.doi.org/10.1016/S0377-2217(99)00433-6. 